\title{
BAEOTHRYON ALPINUM (L.) T.V. EGOROVA (CYPERCAEAE) IN THE POLISH LOWLANDS: DISTRIBUTION, POPULATION DECREASE AND IMPLICATIONS FOR CONSERVATION
}

\author{
PAWEŁ PAWLIKOWSKI \\ Department of Plant Ecology and Environmental Conservation, University of Warsaw \\ Al. Ujazdowskie 4, 00-478 Warszawa, Poland \\ e-mail: p.pawlikowski@uw.edu.pl
}

(Received: October 21, 2009. Accepted: May 12, 2010)

\begin{abstract}
A total of 47 localities of Baeothryon alpinum, hosting population of more than 100000 shoots, were recorded in the lowland part of Poland during field surveys in the years 2003-2009. Among them were 25 populations discovered for the first time. Out of 57 sites of the species known from literature and unpublished (including herbarium) sources, 35 were not confirmed during the survey, 27 of them being definitely extinct. B. alpinum shows a clear pattern of distribution in Poland, with three main areas of occurrence: 1) the north-easternmost Poland (Lithuanian Lake District with the adjacent parts of the Masurian Lake District and the upper Biebrza river valley in North Podlasie Lowlands), which is part of the species boreal main range; 2) scattered localities in north-western Poland; 3) mountain mires at higher altitudes in the Sudetes and Tatra mountains and the adjacent part of southern Poland. The main aggregation of localities is found in Augustów Forest (including the Sejny Lakeland and Wigry National Park), and in the Góry Sudawskie region with adjacent areas. The biggest Polish population in the "Kobyla Biel" fen near Augustów consisted of several dozens of thousands of shoots. The Lithuanian Lake District is an area of general importance for the conservation of B. alpinum in Poland. The species is threatened, first of all, due to secondary succession (mires overgrowing with shrubs, trees and reed) and requires conservation measures as well as establishing nature reserves in places where it occurs. The degree that $B$. alpinum decreases in number is strikingly different in particular regions of Poland - it has lost most of its localities in north-western Poland and in Masurian Lake District, while in the Lithuanian Lake District and the upper Biebrza valley there are minor losses only. Depending on the region (from the west to the east and from the south-west to the north-east), the species should be given extinct or critically endangered (regions of north-western and southern Poland), endangered (Masurian Lake District), vulnerable (North Podlasie Lowlands) and near threatened (Lithuanian lake District) status. Although the disappearance of the populations beyond the species main range is a common phenomenon, the presented pattern is man-related and connected with differences in land management.
\end{abstract}

KEY WORDS: Baeothryon alpinum, Trichophorum alpinum, Cyperaceae, threatened species, distribution, conservation status.

\section{INTRODUCTION}

Baeothryon alpinum (L.) T.V. Egorova (= Trichophorum alpinum (L.) Pers., Scirpus hudsonianus (Michx) Fernald, Eriophorum alpinum L.) is a perennial mire plant forming loose mats. Shoots $10-40 \mathrm{~cm}$, terminate with a single spikelet, 5-7 mm long and ca. $3 \mathrm{~mm}$ wide, ellipsoid to lanceolate. Perianth bristles 4-6, cotton-like in appearance, white, smooth, up to $25 \mathrm{~mm}$ long (DeFilipps 1980). This circumpolar species is bound primarily to the boreal (taiga) zone and the mountain areas southwards. In Europe it is widespread in Scandinavia, northern Russia and the Baltic countries. Its main distribution range extends to Denmark and north-easternmost Poland. Scattered lowland localities are known from northern Germany, western part of Poland and the upper Don area in central Russia, whereas quite numerous mountain populations are found in mountain ranges of central and southern Europe, e.g. the Alps, Pyrenees, Carpathians, Sudetes and Apennines (Hultén and Fries 1986a, b).

The distribution of Baeothryon alpinum in Poland shows a distinct pattern, with three separate areas of occurrence. The main area, which is considered as part of the species boreal range, covers the north-easternmost part of the Polish Lowlands (Lithuanian Lake District with the adjacent parts of the Masurian Lake District and the upper Biebrza river valley). The remaining two areas of occurrence are the post-glacial landscape of north-western Poland and the mountain areas of southern Poland (the Sudetes and Tatra Mountains) with the adjacent, southernmost part of Polish 
lowland (Żukowski 1969; Zając and Zając 2001). The reason for the observed gap in the species distribution in northern Poland (spreading between the Parsęta and Gwda rivers in Pomerania and Śniardwy Lake in Masuria) was a subject of interest of former botanists. Czubiński (1950) presumed that originally the species had a constant distribution in northern Poland, but the area has been divided by several glacier encroachments at the end of the last ice age.

In Poland, the species grows in various mire types, including Sphagnum-dominated poor fens, brown moss-small sedge rich fens (e.g. spring fens) and even in pine-birch fen woodlands (Pałczyński 1975; Sokołowski 1988, 1996; Tyszkowski 1993; Dajdok and Kącki 1999; Łachacz and Olesiński 2000a; Pawlikowski 2008a). During the last century the localities of B. alpinum scattered in Europe beyond the species main range have been vanishing as a result of drainage, secondary succession and management intensification (Dité and Hoskovec 2005). In Poland, the species has lost most of its localities in the western part of the country and is considered vulnerable (VU category - Zukowski 2001). In the countries adjacent to Poland to the south and west, the species is considered critically endangered (Slovakia - Dité and Hoskovec 2005) or endangered (the provinces Mecklemburg-Vorpommern and Schleswig-Holstein in north-eastern Germany - Ingelög et al. 1993; Czech Republic - Dité and Hoskovec 2005). In all of the published Polish regional lists the species is listed as endangered (Western Pomerania - Żukowski and Jackowiak 1995; Polish Carpathians - Piękoś-Mirkowa and Walusiak 2008), critically endangered (Opole Province - Dajdok and Kącki 2002) or extinct (Wielkopolska region - Jackowiak et al. 2007). North-eastern Poland is considered the most important region for the species in Poland (Żukowski 1969, 2001). Nevertheless, there is no clear evidence of that and the population size is unknown. Moreover, the status of about a dozen of localities recorded before the Second World War in the Masurian Lake District (former East Prussia) remains unknown. In the whole country, there is little confirmed information on the disappearance of particular localities. It pertains mainly to populations existing in western Poland (Żukowski 2001) and in the mountains (e.g. near Morskie Oko - Piękoś-Mirkowa and Walusiak 2008). Only the population of B. alpinum in north-eastern Poland whose extinction is sufficiently documented existed in "Spytkowo" nature reserve near Giżycko (Polakowski 1959; Endler and Dziedzic 1991).

The aim of this study is to determine the distribution dynamics of Baeothryon alpinum in Poland and assign the conservation status in particular regions and in the whole country. In order to undertake conservation measures, reliable data on the species distribution dynamics, population size, threats and the status of localities are needed.

\section{METHODS}

A review of literature and all the Polish herbaria collections was carried out to reveal the historical data on the species occurrence in the lowland part of Poland (excluding mountain areas). All the historical localities in northeastern Poland were surveyed in the years 2002-2009 to determine whether the species still occurs there or not. Moreover, suitable habitats were checked in order to find unk- nown populations. In all the localities confirmed or discovered, the abundance of the species was estimated and the threats were listed. In the case of extinct or probably extinct localities, the possible reasons for extinction were determined. Herbarium specimens collected during the field survey were deposited in the Herbarium of Faculty of Biology (WA) at University of Warsaw.

Every locality was assigned an appropriate ATPOL grid square (Zając 1978; Zając and Zając 2001) and rated to appropriate geographical region (Kondracki 2001). When possible, apart from the $10 \times 10 \mathrm{~km}$ squares, smaller $5 \times 5 \mathrm{~km}$ quarters (one-fourth of the big square) were applied. For example, letter "A" denotes north-west quarter, letter "B" denotes north-east quarter and so on. In cases when several local populations existed within one large peatland, they were treated as one locality (unless they were located in different ATPOL squares).

As a result of the field, herbarium and literature survey of Baeothryon alpinum distribution in the Polish Lowlands, a map of distribution was prepared. Mountain localities were also included, based on the map of Zając and Zając (2001, and modified using the data presented by PiękośMirkowa and Walusiak 2008).

\section{RESULTS}

ATPOL grid square codes are given next to the locality name. Explanations of abbreviations: BPN - Biebrza National Park; comm. - commune; Ex - sites extinct due to habitat destruction; Ex? - sites most probably extinct; pers. comm. - personal communication; res. - nature reserve; settl. - settlement; v. - village; WPN - Wigry National Park; * - localities threatened due to secondary succession (trees, shrubs or reed); ** - localities severely threatened due to secondary succession; ! - Paweł Pawlikowski unpublished data. Abbreviations of the names of herbaria follow Mirek et. al. (1997). Population size is presented using intervals: 1 - several up to several dozens of shoots, $2-$ several hundreds of shoots, 3 - several thousands of shoots; 4 - more than 10000 shoots. In the case of localities recorded before the Second World War by German botanists, the former names are cited in [brackets]. Dates of the last confirmed field sightings are given using bold.

\section{List of reliable localities \\ in Poland excluding mountain areas}

\section{SzCZECIN CoAsT}

AB95B meadows [Maduewiesen] near Miedwiecko settl. next to Zieleniewo v. and Miedwie Lake, Kobylanka or Stargard Szczeciński comm. (Holzfuss 1940; Czubiński 1950; Żukowski 1969). Ex (Żukowski 2001). 1850

\section{West Pomerania Lake District}

BB32 near Głodzino v., Rąbino comm. (Czubiński 1950; Żukowski 1969). Ex (Żukowski 2001). unknown (before ca. 1939)

BB43 Połczyn-Zdrój town, Połczyn-Zdrój comm. (Czubiński 1950; Żukowski 1969). Ex (Żukowski 2001). 1912

\section{South Pomerania Lake District}

BC05D "Trzęsacz" [Nakeler Faulen Bruch] fen in "Wielki Bytyń" res., east of Wielki Bytyń Lake [Grosser Böthin- 
see], Wałcz comm. (Abromeit 1928; Frase 1930; Abromeit et al. 1931-40; Czubiński 1950; Balcerkiewicz and Markowski 1969; Żukowski 2001; W. Żukowski, pers. comm. in 2008). Ex? (W. Stachnowicz, pers. comm. in 2009) due to overgrowing with trees and reed. 1983

\section{LUBUSZ LAKE DisTRICT}

BC91C "Jeziora Gołyńskie" res., peatland adjacent to Mały Gołyń Lake [Kleine Golynsee] south-west of Pszczewo v., Pszczewo comm. (Frase 1930; Żukowski 1969). Ex (Żukowski 2001). 1928

\section{SILESIAN LOWLANDS}

CE87B "Kamieniec" res., poor fen in Budkowiczanka river valley east of Kamieniec settl., Lasowice Wielkie comm. (Dajdok, Kącki 1999; A. Nowak, pers. comm. in 2009: 1). 2003*

\section{SiLESIAN HighlandS}

DF22C Sucha Góra, district of Bytom city, Bytom comm (Zapałowicz 1906; Żukowski 1969). Ex (Żukowski 2001). 1875

\section{MASURIAN LAKE District}

EB68B Masurian Scenic Park, "Bagno Mulaste" (Bagno Muliste) fen bordering small lakes south of Zgon [Sgonn] v., Piecki or Świętajno comm. (Abromeit 1928; Abromeit et al. 1931-40, Żukowski 1969). Ex? (! 2009), but small patches of suitable habitat still exist. 1922

FA83D peatland near Mażucie [Masutschen] v., Gołdap comm. (Abromeit 1928; Abromeit et al. 1931-40). Ex (! 2009) due to peat extraction, drainage and overgrowing with trees. 1925 or 1926

FA83B peatland near Wiłkajcie [Wilkatschen] v., Gołdap comm. (Abromeit et al. 1931-40). The paper containing the original data of F. Brauer (see Abromeit et al. 193140) has not been revealed in the present study. Ex (! 2009) due to peat extraction, drainage and overgrowing with trees. 1931

FA83C peatland near Audyniszki [Audinischken] v., Banie Mazurskie comm. (Abromeit et al. 1931-40). Ex (! 2009) due to peat extraction, drainage and overgrowing with trees and shrubs. This locality is not mentioned in the original paper of Abromeit (1928), which includes other nearby recordings of the species by $\mathrm{R}$. Büchle (see Abromeit et al. 1931-40). 1925

FA91C fen in the place of non-existing lake near Kalskie Nowiny [Kehlerwald] v. between Węgorzewo and Stręgiel, Wegorzewo comm. (Führer 1928; Abromeit 1928; Abromeit et al. 1931-40; Żukowski 1969). Ex (! 2009) due to drainage and overgrowing with trees. between 1917 and 1920

FA94A peatland [Johannisberger Moor] south-west of Janowo [Johannisberg] v., Gołdap comm. (Kaunhowen and Range 1906). Ex (! 2009) due to overgrowing with trees and peat extraction. 1905

FA94B poor fen bordering a small lake near the top of the Tatarska Góra [Tataren Berg, Friedrichower Berg] hill, Gołdap comm. (Schultz 1892; Abromeit 1898; Kaunhowen and Range 1906, Gross 1912; Abromeit et al. 193140). Ex (Łachacz and Olesiński 2000b, ! 2002-2004, 2006, 2009,), most probably due to acidification (but small patches of suitable habitat still exist). Gross (1910) erroneously cited the name of the hill as "Seesker Berg" (see Łachacz and Olesiński 2000b). 1908 or 1909

FB11B fen in "Spytkowo" [Spiergsten] res., Giżycko comm. (Gross 1910; Abromeit et al. 1931-40, Polakowski 1959). Ex (Endler and Dziedzic 1991) due to drainage and overgrowing with trees and shrubs. ca. 1957

FB26D fen bordering a small lake [Widny-See, Widnysee] that does not currently exist, in a forest north-east of Kleszczewo [Kleszöwen] v. and east of Nory settl., Wieliczki comm. (Grütter 1897; Abromeit et al. 1931-40; Żukowski 1969, ! 2009: 3). 2009**

FB26D fen in a forest west of Dorsze [Dorschen] v., Wieliczki comm. (Abromeit et al. 1931-40). Ex (! 2009) due to drainage, forest development and mire acidification. The paper containing the original data of G. Rehse (see Abromeit 1931-1940) has not been revealed in the present study. 1892

FB27D fen north of Zocie [Soczien] v., Kalinowo comm. (Steffen 1912, 1914; Abromeit et al. 1931-40; Żukowski 1969; specimens in UGDA: leg. J. Bloch 2001; BlochOrłowska and Pisarek 2005, ! 2003, 2009: 3). 2009*

FB34D peatland near Mleczkowo [Milchbude] settl., forest south of Malinówka Wielka v. and east of Oracze v., Ełk comm. (Gross 1910, 1912; Abromeit et al. 1931-40; Żukowski 1969). Ex (! 2009) due to drainage and overgrowing with trees and reed. 1908 or 1909

FB35B fen bordering a small lake [Mechatzsee] southwest of Czaple v., Ełk comm. (Koppe and Koppe 1931). Ex (! 2009) due to eutrophication, drainage and overgrowing with reed. 1930

FB35B fen bordering the west part of Godle Lake near Chełchy [Chelchen] v., Czaple [Zappeln] v. and Przykopka [Birkenwalde, Przykopken] v., Ełk comm. (Koppe and Koppe 1931; Abromeit et al. 1931-40; Żukowski 1969). Ex (! 2009) due to overgrowing with trees and shrubs, drainage and peat extraction. The paper containing the original data of H. Steffen (see Abromeit et al. 193140) has not been revealed in the present study. 1936

FB35C fen bordering a small lake in a forest [Dallnitzwald] north-east of Ełk town, Ełk comm. (Gross 1910; Abromeit et al. 1931-40). Ex (! 2009) due to overgrowing with trees and drainage. 1908 or 1909

FB41B "Jeziorko koło Drozdowa" res., fen east of Drozdowo, Orzysz comm. (Łachacz and Olesiński 2000a, ! 2009: 2). 2009

FB45C fen bordering Tatary Duże Lake [Grosse Tatarensee] south of Ełk, Ełk comm. (Kalkreuth 1914; Abromeit 1928; Abromeit et al. 1931-40; Żukowski 1969). Ex (! 2009) due to overgrowing with trees and drainage. 1924

FB50 fen bordering the east part of Bełdany Lake, Ruciane-Nida comm. (KRA: leg. A. Kornaś; J. Kornaś 1952; Żukowski 1969). Ex (! 2009) due to overgrowing with trees. 1952

FB60 mire bordering Gaik (Kaik) Lake [Kaiksee] by Guzianka Wielka Lake (part of the Bełdany Lake system), east of Ruciane [Rudszanny] settl., which is a part of Ruciane-Nida town, Ruciane-Nida comm. (Büchle 1930; Abromeit et al. 1931-40; KRA: leg. J. Kornaś 1952; leg. J. Staszkiewicz 1952; Żukowski 1969). Ex (! 2009) due to overgrowing with trees. 1952 


\section{LITHUANIAN LAKE DISTRICT}

FA77D fen adjacent to Burniszki v., Wiżajny comm. (Kawecka 1991). Ex (! 2008) due to drainage, peat extraction, mire acidification and overgrowing with trees and shrubs. between 1979 and 1987

FA77D fen adjacent to Grzybina v., Wiżajny comm. (! leg. 2008: 2). 2008**

FA78C fen adjacent to Stankuny v., Wiżajny comm. (! leg. 2008: 2). 2008

FA78C fen adjacent to Kolonia Wiżajny settl., Wiżajny comm. (! leg. 2008: 2). 2008

FA78C fen bordering the south-eastern part of Prudel Lake, Wiżajny comm. (! 2008: 2). 2008

FA79C "Plinia" fen adjacent to Ejszeryszki v. and state border, Rutka-Tartak comm. (! leg. 2008: 2). 2008

FA88B fen bordering a small lake ("Kamionka") between Rowele v. and Makowszczyzna v., Wiżajny comm. (WA: leg. Z. Podbielkowski 1974; Kłosowski and Tomaszewicz 1979). Ex? (! 2008), most probably due to acidification and overgrowing with trees. between 1973 and 1977

FA88C poor fen bordering the north part of Czarne Lake by Smolniki v., Wiżajny comm. (BIL: leg. A.W. Sokołowski 1969, Sokołowski 1973). Ex? (! 2009), most probably due to overgrowing with trees and shrubs and peat extraction, but small patches of suitable habitat still exist. 1969

FA89D poor fen between Andrzejewo and Szymanowizna v., Szypliszki comm. (BIL: leg. A.W. Sokołowski 1986; Kawecka 1991, ! leg. 2004, ! 2008: 1). 2008**

FA89D fen adjacent to Kociołki v., Szypliszki comm. (! leg. 2008: 3). 2008*

FA97B Suwałki Scenic Park: fen east of Boczniel (Boczne) Lake near Błaskowizna v., Jeleniewo comm. (BIL: leg. A.W. Sokołowski 1975; Gos and Gos 1991; Kawecka 1991, ! leg. 2004: 2). 2004*

FA98B fen "Dziobel" east of Gulbieniszki, Jeleniewo comm. (Pawlikowski 2008a, ! leg. 2006: 1). 2006*

FA98D bog margin near Sidorówka v. near Jeleniewo, Jeleniewo comm. (Pawlikowski 2008a, ! leg. 2004: 1). 2004*

FA98D fen west of Udryn v., Jeleniewo comm. (BIL: leg. A. Kawecka 1980; Kawecka 1991). Ex (! 2004) due to drainage and overgrowing with trees and shrubs. 1980

FA99A fen adjacent to Przejma Wielka v., Szypliszki comm. (BIL: leg. A.W. Sokołowski 1986; Kawecka 1991, ! leg. 2004: 2). 2004*

FA99A fen west of Szypliszki v., Szypliszki comm. (Kawecka 1991). Ex (! 2008-2009) due to overgrowing with trees. between 1979 and 1987

FB07C peatland near Zusno v., Filipów comm. (BIL: leg. A. Dackiewicz 1969). Ex (! 2009) due to peat extraction, overgrowing with trees and drainage. 1969

FB08A Czarna Hańcza river valley, spring and rich fen complex between Osowa v. and Potasznia v., west of the river, Suwałki comm. (! leg. 2004, ! 2003-2005: 2). 2005

FB17A Rospuda river valley, "Bagno Parchacz" rich fen near Stara Kamionka v., Bakałarzewo comm. (! 2003, 2004: 3). 2004**

FB19A WPN: Czarna Hańcza river valley west of Wigry Lake, fen south of the river, Suwałki comm. (Sokołowski 1990; Jutrzenka-Trzebiatowski et al. 2002, ! 2003, 2009: 3). 2009*
FB19B WPN: fen on Rosochaty Róg peninsula, Krasnopol comm. (Sokołowski 1990; Jutrzenka-Trzebiatowski and Szarejko 2001; Jutrzenka-Trzebiatowski et al. 2002, ! 2003: 2). 2003

FB19D WPN: Jurkowy Róg peninsula, rich fen between Kruszyn (Krusznik) Lake and Wigry Lake, Nowinka comm. (! 2004-2005: 2). 2005**

FB19D WPN: rich fen bordering the north-east part of Kruszyn (Krusznik) Lake, Nowinka comm. (Sokołowski 1990, Jutrzenka-Trzebiatowski et al. 2002). Ex? (! 2009) due to overgrowing with reed, trees and shrubs, but small patches of suitable habitat still exist. between 1992 and 1999

FB28D Rospuda river valley, rich fen west of the river, east of the Topiłówka v., Augustów comm. (! 2006: 2). 2006

FB39A Rospuda river valley, forested mire east of the Rospuda river, south of the Blizna river and east of the Kozia Szyja hill, Augustów comm. (Sokołowski 1989, ! 2003, 2007, 2009: 3). This is possibly the place where W. Szafer collected the specimens in 1929 (KRA). 2009

FB39A Rospuda river valley, rich fen west of the river, near Rospuda Lake, Augustów comm. (Sokołowski 1989, ! 2006, 2008: 3). 2009*

FB39A "Kobyla Biel" rich fen bordering the north-west part of Białe Augustowskie Lake, Nowinka comm. (Tyszkowski 1992, 1993, ! leg. 2004, ! 2004-2009: 4). 2009*

FB39B "Kalejty" res., rich fen bordering the eastern part of Kalejty (Długie) Lake, Nowinka comm. (BIL: leg. A.W. Sokołowski 1972, ! 2009: 2). 2009**

FB39B "Kalejty" res., rich fen bordering a small lake near Przewięź settl., Augustów comm. (! leg. 2009: 2). 2009

FB39C rich fen adjacent to allotment gardens in Augustów, near "Szosa do Sejn" road, Augustów comm. (! leg. 2006: 2). 2006*

FB49C rich fen bordering the south-western part of Kolno Lake, Augustów comm. (POZ: leg. R. Plackowski 1978; Plackowski 1980). Ex (!2003) due to drainage and mire overgrowing with trees and shrubs. 1978

GA90C rich fen $1 \mathrm{~km}$ east of Nowe Boksze v., near Czarna river valley, Krasnopol comm. (! leg. 2004: 3). 2004**

GA90C margin of the bog south of Boksze Lake, Punsk comm. (! leg. 2006: 1). 2006

GB00A fen south of Buczniel (Boczniel) Lake near Podlas v., Krasnopol comm. (! leg. 2004: 1). 2004**

GB00B poor fen bordering the north part of Płaskie Lake, Sejny comm. (WA: leg. L. Bogdanowicz 1975; Kłosowski and Tomaszewicz 1979; S. Kłosowski, pers. comm. in 2008). Ex? (! 2009) due to overgrowing with reed, trees and shrubs, but small patches of suitable habitat still exist. 1999

GB00B "Magdzie Bagna" sparsely wooded rich fen bordering the south-west part of Płaskie Lake, Krasnopol comm. (! leg. 2004: 2). 2006*

GB00C rich fen between Długie Lake and a small lake northwards, Krasnopol comm. (! leg. 2003, ! 2006: 1). 2006*

GB01B rich fen bordering the west part of Dusajtis (Dafrajtis) Lake (near Dusznica v.), Sejny comm. (! 2004: 2). 2004

GB01B fen bordering Druce (Drucieżerys) Lake, Sejny comm. (KRA: leg. R. Ochyra 1977, Żukowski 2001, UGDA: leg. J. Bloch 2002, ! 2004, 2007: 3). 2007 
GB02C rich fen bordering the east part of Gajlik Lake, Sejny comm. (Jabłońska 2005, ! 1999-2009: 2). 2009

GB10D rich fen west of Sarnetki (Sernetki) v., Giby comm. (! 2003-2007: 2). 2007*

GB11B fen bordering Dowcień Lake near Pomorze Lake, Giby comm. (WA: leg. B. Sudnik 1975, leg. Mazek 1975, Mazur et al. 1978, Kirpluk 1992). Ex (! 2003, 2005) due to overgrowing with trees, but small patches of appropriate habitat still exists. ca. 1990

GB11D rich fen bordering the south-west part of Wiłkokuk Lake, Giby comm. (BIL: leg. A.W. Sokołowski 1974, WA: leg. J. Popławska 1975, KRAM: leg. R. Ochyra 1977, Sokołowski 1978, Kłosowski and Tomaszewicz 1979, ! 2004-2007: 3). 2007

GB11D rich fen $0,5 \mathrm{~km}$ south-west of the southernmost part of Wiłkokuk Lake, Giby comm. (Sokołowski 1978, ! 2004: 2). 2004

GB12A "Łempis" res., fen bordering Stulpieniuk Lake, Sejny comm. (! leg. 2004: 2). 2004

GB12C rich fen "Mielubagno" bordering the north-east part of Zelwa Lake, Giby comm. (! leg. 2004: 2). 2004*

GB12C rich fen between Zelwa Lake and Seklis Lake, Giby comm. (Kłosowski and Tomaszewicz 1979, ! 20032007: 3). 2007

GB21A fen bordering Hilinki (Chylniki) Lake and a small lake northwards, Giby comm. (Tyszkowski 1995, ! leg. 2006: 2). 2006*

GB30B rich fen in a small valley reaching the Augustowski Canal valley, between Żyliny settl. (near Sucha Rzeczka v.) and Żydowskie settl. (near Płaska v.), Płaska comm. (Tyszkowski 1995, ! 2006: 2). 2006*

GB32A? Augustowski Canal valley, fen adjacent to Rygol v., Płaska comm. (BIL: leg. J. Żurawski 1974). Ex? (! 2009). There are several fens adjacent to that village and the precise location has not been revealed, but the species does not occur in any of them. 1974

\section{NORTH PODLASIE [PoDlachia] LoWLANDS}

FB56D fen south of Bełda v., Rajgród comm. (Żukowski 1969). Ex (! 2009) due to drainage and intensive meadow management. 1956

GB40 mire near Jastrzębna v., Sztabin comm. (Żukowski 1969). The locality is imprecise, but most probably Ex? (! 2002, 2009) due to drainage, intensive meadow management and forest development. 1954

GB41C BPN: Biebrza river valley, north of the river, fens south of Nowy Lipsk v., Lipsk comm. (! 2008: 3). 2008

GB41D Biebrza river valley, north of the river, fens between Nowy Lipsk v. and Lipsk v., north of the Lipsk - Jastrzębna road, Lipsk comm. (! 2008: 2). 2008*

GB41D BPN: Biebrza river valley, south of the river, fens adjacent to Jałowo v., Lipsk comm. (Pałczyński 1988; ! 2003: 2). 2003**

GB51B BPN: Biebrza river valley, south of the river, fens adjacent to Szuszalewo v. and Kropiwna v., Dąbrowa Białostocka comm. (Pałczyński 1988, ! 2003, 2009: 3). 2009*

\section{LIST OF UNCERTAIN LOCALITIES}

AD09 Jordanowo v., Świebodzin comm. (Żukowski 1969). The original paper of Ulbrich (1916) (see Żukowski 1969) does not contain information on the species and the area mentioned.
CC16 Smukała, present district of Bydgoszcz city, Bydgoszcz comm. (Zając and Zając 2001; ATPOL database after Bock 1908). The original paper of Bock (1908) does not contain information on the species.

DF35 Strzemieszyce, present district of Dąbrowa Górnicza city, Dąbrowa Górnicza comm. (Zając and Zając 2001; ATPOL database after herbarium specimens collected by A. Sendek in 1976). There is no other information on this locality.

FA84C peatland $2 \mathrm{~km}$ west of Gołdap, Gołdap comm. ( $\dot{\mathrm{Z}} \mathrm{u}-$ kowski 1969). This locality is uncertain, as it can be identical with the listed above locality near Wiłkajcie.

In Poland, the number of localities of the species recorded so far is estimated at 82. The main area of the species occurrence in Poland are the Lithuanian Lake District (50 localities), the eastern part of the Masurian Lake District (19 localities) and the Biebrza river valley in North Podlasie Lowlands (6 localities). The distribution of the species in the area studied as well as the status of the localities are presented in Figure 1.

My survey revealed the presence of Baeothryon alpinum at 47 localities in the Polish Lowlands after the year 2000. Among them were 25 populations previously unknown, discovered by the author. Twenty-seven localities are definitely extinct, and 8 are most probably extinct. The main reasons for extinction are: overgrowing with trees and shrubs, drainage, peat extraction and expansion of reed.

There is clear imparity between the conditions of populations in the two neighbouring areas (Fig. 2). Considering the localities known before the year 2000 only, the Lithuanian Lake District has 14 (39 in total) populations confirmed after the year 2000 (56\%), whereas in the Masurian Lake District only 3 populations have been confirmed (16\%). Most of the localities in the Lithuanian Lake District are concentrated in the borderline areas of Augustów Forest, including the Sejny Lakeland and Wigry National Park, and in Góry Sudawskie region and adjacent areas.

Moderately abundant populations (several hundreds of shoots) predominate, comprising more than a half $(57 \%)$ of the total number of populations. As many as $15 \%$ of the localities host very small populations (less than 100 shoots), but as many as 14 populations (nearly 30\%) are numerous (more than 1000 shoots). They were noted in the Lithuanian Lake District (10 populations), as well as in the Masurian Lake District (2 populations) and the upper Biebrza area (2 populations). It is difficult to estimate the size of the biggest population (in the "Kobyla Biel" fen bordering Białe Augustowskie Lake), since it densely covers an area of more than 5 hectares. There are 28 localities (60\%) that are threatened due to secondary succession, nine of them being severely threatened.

\section{DISCUSSION}

Young postglacial landscapes favour the development of peatlands (Tobolski 2003), which are the habitat of Baeothryon alpinum. Many of the mire plants in Poland occur mostly in lakeland areas in north and north-western part of the country (see Zając and Zając 2001). In the case of north-easternmost Poland, the high abundance of mire species is associated with greater availability of suitable habi- 


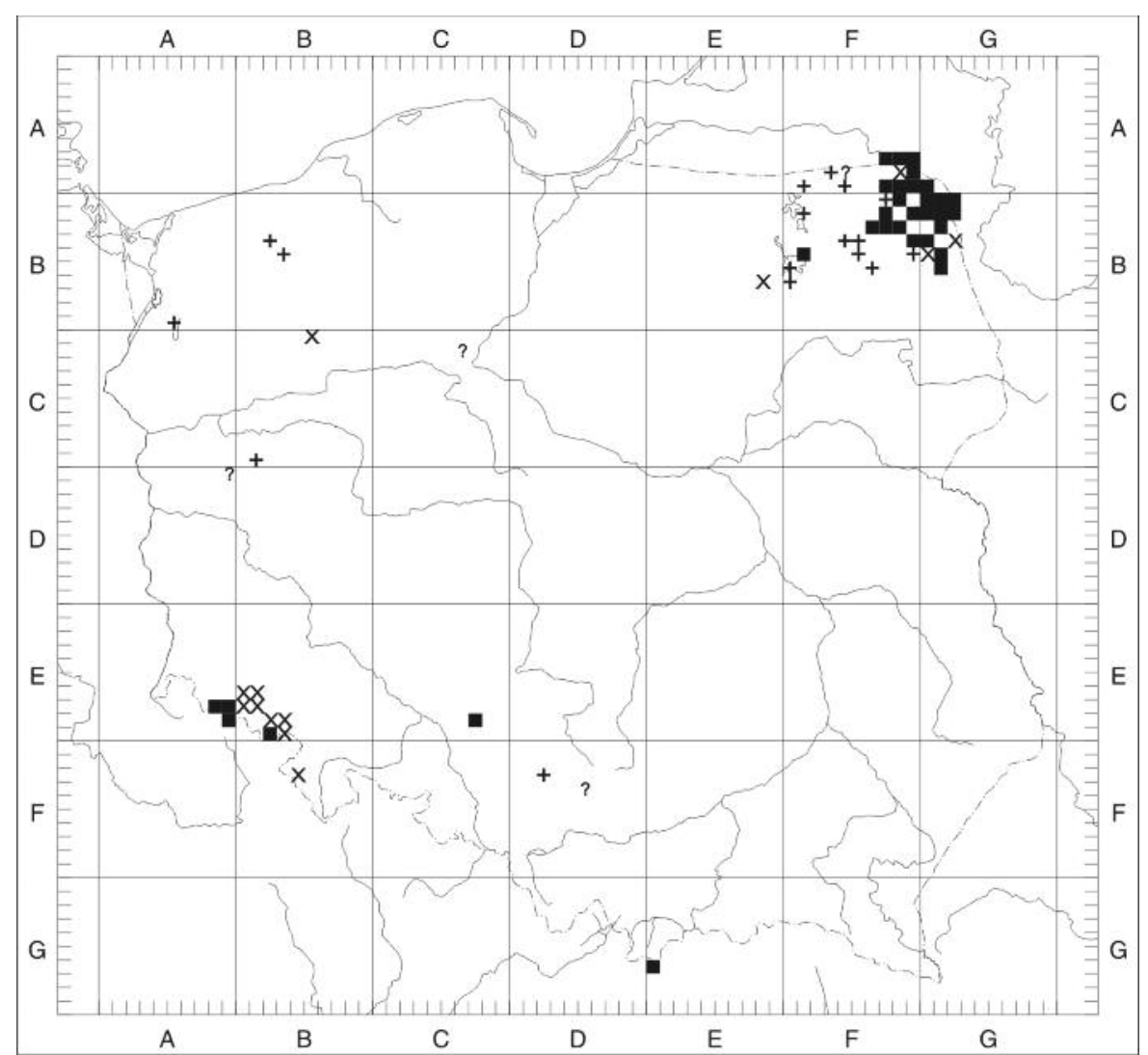

Fig. 1. Distribution of Baeothryon alpinum in Poland: - locality confirmed after the year $2000 ; \times$ - locality probably extinct; + extinct locality; ? - uncertain locality. tats (and postglacial history of plant cover - Środon 1972). Moreover, the influence of boreal climate which is stronger in north-eastern Poland than in other parts of the country (Kondracki 2001) can favor the occurrence of boreal species, since many of the plants occurring in peatland ecosystems in Central Europe are bound primarily to the taiga zone (see Hultén and Fries 1986a, b). This is particularly true in the case of B. alpinum as nearly all the lowland localities of the species are situated in the lakeland areas of northern Poland, and are mostly aggregated in the northeasternmost part of the country.

The number of existing localities of Baeothryon alpinum known from the Lithuanian Lake District is surprisingly high in comparison with the adjacent Warmia and Masuria region, which shared similar geological (glacial) history and is geomorphologically similar (Kondracki 2001). Bloch-Orłowska (2007), who investigated Carex chordorrhiza (a mire species that shows a pattern of distribution dynamics similar to that of $B$. alpinum), pointed out that because of climate-related reasons the localities beyond the species main range are particularly vulnerable to accelerated decrease in number. Since many of the populations of C. chordorrhiza in north-eastern Poland still persisted, the author concluded that extinctions involved mostly the localities situated beyond the climatic optimum for the species. But if climatic factors explain why many mire species survived best in the north-easternmost Poland, the above pattern should be observed among boreal species only.

An argument against this theory is the example of Liparis loeselii, an important fen species not related to the boreal zone (it occurs mainly in Central Europe - Hultén and Fries 1986b). It has lost most of its previously recorded localities in Poland, and the majority of the populations survived in the Lithuanian Lake District in north-eastern Po- land (Pawlikowski 2008b), where the boreal climatic influences are strongest. This suggests that independently of the species distribution, special attention should be given to man-related factors, particularly the intensification of land management (e.g. drainage). Despite different distribution patterns, both $B$. alpinum and $L$. loeselii have the most vital populations in north-easternmost Poland. Apart from the climatic factors, the most important reasons for this situation seem to be related to the fact that in the Lithuanian Lake District traditional extensive land management practices continued until very recently, whereas in many other lakelands in north-eastern Poland (including Masuria and Warmia territory) the area was intensively managed and drained before and after World War II. This confirms the opinion of Jasnowski et al. (1968), who proved that the disappearance of mire plant species is caused primarily by human activity.

This pattern of decrease is true in the case of many other rare and endangered mire species with various distribution, such as Saxifraga hirculus, Hammarbya paludosa, Malaxis monophyllos, Betula humilis and Eriophorum gracile (Kaźmierczakowa and Zarzycki 2001; Zając and Zając 2001). Furthermore, the explanation based on the regional differences in land-use intensity is strengthened by the fact that many species considered threatened in Poland, are not threatened at all in the Lithuanian Lake District (e.g. Sokołowski 1973, 1990; Kawecka 1991; Pawlikowski 2008a, c).

There have been little data on the population size of Baeothryon alpinum at the localities in Poland until now. Both very abundant (Tyszkowski 1992; Żukowski 2001; BlochOrłowska and Pisarek 2005) and small (Balcerkiewicz and Markowski 1969; Plackowski 1980; Dajdok and Kącki 1999; Pawlikowski 2008a) populations were recorded. The high number of shoots in the Lithuanian Lake District, with 


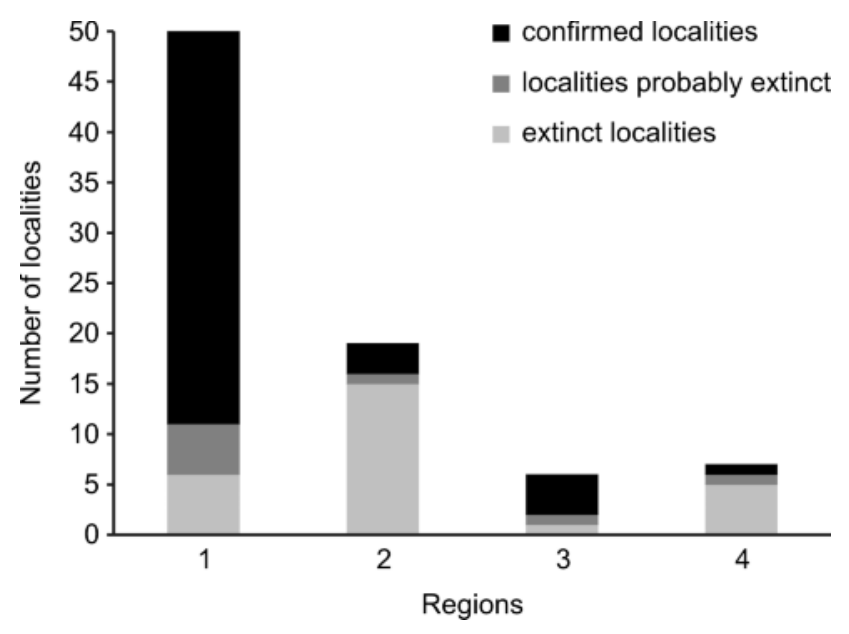

Fig. 2. Number of localities and their status in particular regions of lowland Poland. 1 - Lithuanian Lake District; 2 - Masurian Lake District; 3 North Podlasie Lowlands; 4 - other regions.

at least 9 populations exceeding 1000 shoots, indicates that the Polish part of the Lithuanian Lake District hosts the majority of the Polish resources of the species. The estimated total number of shoots in the Lithuanian Lake District probably reaches 100000 , while in both neighbouring regions (Masurian Lake District, upper Biebrza valley) it does not exceed 10000 . The last two lowland populations confirmed during the past decades in southern and western part of Poland are on the verge of extinction.

In the part of Belarus adjacent to Poland, B. alpinum has not been recorded since the 19th century, and the species has the status of vulnerable species for the whole country (Skuratovich 2005). At the same time, it is considered not threatened at all in nearby Lithuania (Rašomavičius 2007). Thus, the aggregation of vital populations of Baeothryon alpinum in the Lithuanian Lake District with the adjacent areas is part of the species main range that includes nearby Lithuania (Hultén and Fries 1986a). This is in contrast to the remaining, scattered lowland localities beyond the main range of the species, all of them being extinct or near extinction.

As the number of populations of Baeothryon alpinum in Poland is decreasing, conservation measures should be undertaken where needed, and nature reserves established that would protect the most important (best preserved or most numerous) populations of the species. At present, apart from the six confirmed populations in the Biebrza National Park and the Wigry National Park, there are five confirmed populations situated within the borders of nature reserves. Among the localities that should be designated as nature reserves are:

(1) fens in the lower Rospuda river valley;

(2) "Kobyla Biel" fen bordering north-western part of Białe Augustowskie Lake;

(3) "Bagno Parchacz" fen near the village of Stara Kamionka;

(4) a fen north-east of the village of Kleszczewo.

Populations (2-4), as well as those in the Biebrza National Park, need active protection (removing of shrubs and trees, sometimes also restoring proper hydrological conditions).

When the IUCN definitions of categories of threat (IUCN...2008) are applied, Baeothryon alpinum should be treated as Vulnerable (VU) in Poland, since A2c+3c criteria are met. When assessing the species status at a smaller geographical unit, the threat categories vary between the particular regions of lowland Poland. These are as follows:

- Critically Endangered (CR) - Masurian Lake District (criteria A2c+3c; B1ab(i-iv)+2ab(i-iv)) and Silesian Lowlands (criterion D; see Dajdok and Kącki 2002);

- Vulnerable (VU) - Northern Podlasie Lowlands (criteria $\mathrm{B} 1 \mathrm{ab}(\mathrm{i}-\mathrm{iv})+2 \mathrm{ab}(\mathrm{i}-\mathrm{iv})$, but the category of threat is downgraded, since populations within the region may experience a "rescue effect" from populations in the neighbouring Lithuanian Lake District; see IUCN 2003);

- Near Threatened (NT) - Lithuanian Lake District (the species does not qualify for VU category now, but is close to qualifying for and is likely to qualify for a VU category in the near future).

In the South Pomerania Lake District Baeothryon alpinum has been considered critically endangered (Źukowski and Jackowiak 1995), but it has now become clear that the species should be regarded most probably extinct. Its only population in the "Trzęsacz" nature reserve has not been confirmed since 1983. It is beyond dispute that the species is extinct $(\mathrm{Ex})$ in all the other regions of lowland Poland where it used to occur.

\section{ACKNOWLEDGEMENTS}

I would like to thank Prof. S. Kłosowski and Filip Jarzombkowski M.Sc. for their assistance during the field survey, Dr. Dan Wołkowycki for his help in applying the IUCN criteria, and the Curators and the Staff of the Polish herbaria for providing information and access to herbarium collections. I am indebted to Prof. W Żukowski, Dr. Z. Dajdok, Dr. A. Nowak and Dr. W. Stachnowicz for the valuable information about the status of lowland localities of Baeothryon alpinum in western and southern Poland. I am also grateful to Prof. Adam Zając for providing me with the ATPOL database information. The study was supported in part by the Ministry of Science and Higher Education (former State Committee for Scientific Research), through the Faculty of Biology, University of Warsaw intramural grants: BW 1601/5 and BW 1636/40, and by the Ministry of Science and Higher Education (grant N 304010 31/0414).

\section{LITERATURE CITED}

ABROMEIT J. 1898. Bericht über die 36. Jahresversammlung des Preussischen Botanischen Vereins am 5. Oktober $1897 \mathrm{zu}$ Goldap. Schr. phys.-ökon. Ges. Königsberg 39: 18-72.

ABROMEIT J. 1928. Neue und bemerkenswertere Pflanzenfunde in Ostpreussen und den benachbarten Gebieten. Schr. phys.ökon. Ges. Königsberg 65(3/4): 182-238.

ABROMEIT J., NEUHOFF W., STEFFEN H. 1931-1940. Flora von Ost- und Westpreussen. 2. Kommissionverlag Gräfe und Unzer, Königsberg, pp. 685-1248.

BALCERKIEWICZ S., MARKOWSKI R. 1969. Trichophorum alpinum (L.) Press. na torfowisku Trzęsacz koło Nakielna pow. Wałcz. Bad. Fizjogr. Pol. Zach. 22: 185-186. (in Polish with English summary)

BLOCH-ORŁOWSKA J. 2007. Carex chordorrhiza (Cyperaceae) w Polsce Północnej - rozmieszczenie i aspekty ochrony. Fragm. Flor. Geobot. Polonica 14(1): 75-90. (in Polish with English summary) 
BLOCH-ORŁOWSKA J., PISAREK W. 2005. Rzadkie i zagrożone rośliny naczyniowe oraz mchy torfowiska Zocie na Pojezierzu Ełckim. Chrońmy Przyr. Ojcz. 61(3): 5-10. (in Polish)

BOCK W. 1908. Taschenflora von Bromberg (Das Netzegebiet). Mittlersche Buchhandlung, Bromberg, pp. xvii +214 .

BÜCHLE R. 1930. Neue und bemerkenswerte Pflanzenfunde in Ostrpreussen und den benachbarten Gebieten. Jahres-Ber. Preuss. Bot. Ver. 1927/29: 1-43.

CZUBIŃSKI S. 1950. Zagadnienia geobotaniczne Pomorza. Bad. Fizjogr. Pol. Zach. 2: 439-658. (in Polish with English summary)

DAJDOK Z., KĄCKI Z. 1999. Baeothryon alpinum (Cyperaceae) na Nizinie Śląskiej. Fragm. Flor. Geobot. Polonica 6: 277-279. (in Polish with English summary)

DAJDOK Z., KĄCKI Z. 2002. Wełnianeczka alpejska Baeothryon alpinum (L.) T.V. Egorova. In: A. Nowak, K. Spałek (eds), Czerwona Księga Roślin Województwa Opolskiego. Rośliny naczyniowe wymarłe, zagrożone i rzadkie. Śląskie Wydawnictwo ADAN, Opole, p. 130. (in Polish)

DEFILIPPS R.A. 1980. Scirpus L. In: Flora Europaea 5. T.G. Tutin, V.H. Heywood, N.A. Burges, D.M. Moore, D.H. Valentine, S.M. Walters, D.A. Webb (eds), Alismataceae to Orchidaceae. Cambridge University Press, Cambridge-Sydney, pp. 277-280.

DITÉ D., HOSKOVEC L. 2005. Trichophorum alpinum (L.) Pres. Suchopýrek alpský. Páperec alpínsky. In: D. Průša, P. Eliáš jun., D. Dité, L. Čačko, P. Krása, Z. Podešva, L. Kovář, M. Průšová, L. Hoskovec, L. Adamec. Chránené rostliny Ćeské a Slovenské republiky. Computer Press, Brno, p. 308. (in Czech)

ENDLER Z., DZIEDZIC J. 1991. Zmiany w składzie florystycznym rezerwatu "Torfowisko Spytkowo” koło Giżycka. Chrońmy Przyr. Ojcz. 47(6): 71-74. (in Polish)

FRASE R.1930. Neue und bemerkenswerte Pflanzenfunde in der Grenzmark Posen-Westpreussen. Abhandlungen und Berichte der Naturwissenschaftlichen Abteilung der Grenzmärkischen Gesellschaft zur Erforschung und Pflege der Heimat 5: 49-84.

FÜHRER G. 1928. Mooruntersuchung in den Kreisen Angerburg und Darkehmen (1917-20). Schr. phys.-ökon. Ges. Königsberg 65(3/4): 164-169.

GOS K., GOS L. 1991. Interesujące torfowisko przejściowe koło Błaskowizny w Suwalskim Parku Krajobrazowym. Zesz. Nauk. Uniw. Gdańsk., Biologia 9: 117-121. (in Polish with English summary)

GROSS H. 1910. Flora des Kreises Lötzen und seiner Grenzgebiete. Jahres-Ber. Preuss. Bot. Ver. 1909: 43-65.

GROSS H. 1912. Ostpreussens Moore mit besonderer Berücksichtigung ihrer Vegetation. Jahresber. Preuss. Bot. Ver. 1911: 61-142.

GRÜTTER M. 1897. Beitrag zur Kenntnis der Flora des Kreise Oletzko und Goldap. Jahres-Ber. Preuss. Bot. Ver. 1896/1897: 48-51.

HOLZFUSS E. 1940. Die Pflanzensammlung des Naturkundenmuseums des Stadt Stettin. Dohrniana 19: 91-105.

HULTÉN E., FRIES M. 1986a. Atlas of North European vascular plants. 1. Koeltz Scientific Books, Königstein, pp. xvi +498.

HULTÉN E., FRIES M. 1986b. Atlas of north european vascular plants. 3. Koeltz Scientific Books, Königstein, pp. 969-1172.

INGELÖG T., ANDERSSON R., TJERNBERG M. 1993. Red Data Book of the Baltic Region. 1. List of threatened vascular plants and vertebrates. Swedish Threatened Species Unit, Uppsala, Institute of Biology, Riga, pp. 95.

IUCN 2003. Guidelines for Application of IUCN Red List Criteria at Regional Levels. Version 3.0. IUCN Species Survival Commission, IUCN, Gland, Switzerland, Cambridge, UK, pp. ii +26 .

IUCN STANDARDS AND PETITIONS WORKING GROUP 2008. Guidelines for Using the IUCN Red List Categories and Criteria. Version 7.0. Standards and Petitions Working Group of the IUCN SSC Biodiversity Assessments Sub-Committee in August 2008. Downloadable from http://intranet.iucn.org/webfiles/doc/SSC/RedList/RedListGuidelines.pdf.

JABŁOŃSKA E. 2005. Flora roślin naczyniowych i mszaków torfowiska nad jeziorem Gajlik na Pojezierzu Sejneńskim. Fragm. Flor. Geobot. Polonica 12(1): 67-81. (in Polish with English summary)

JACKOWIAK B., CELKA Z., CHMIEL J., LATOWSKI K., ŻUKOWSKI W. 2007. Red list of vascular flora of Wielkopolska (Poland). Biodiv. Res. Cons. 5-8: 95-127.

JASNOWSKI M., JASNOWSKA J., MARKOWSKI S. 1968. Ginące torfowiska wysokie i przejściowe w pasie nadbałtyckim Polski. Ochr. Przyr. 33: 69-124. (in Polish with English summary)

JUTRZENKA-TRZEBIATOWSKI A., SZAREJKO T. 2001. Zespół Caricetum buxbaumii w Wigierskim Parku Narodowym. Fragm. Flor. Geobot. Polonica 8: 149-171. (in Polish with English summary)

JUTRZENKA-TRZEBIATOWSKI A., SZAREJKO T., DZIEDZIC J. 2002. Walory florystyczne wybranych obiektów badań geobotanicznych Wigierskiego Parku Narodowego. Acta Botanica Warmiae et Masuriae 2: 63-92. (in Polish with English summary)

KALKREUTH P. 1914. Beitrag zur Flora des Kreises Lyck. Schr. phys.-ökon. Ges. Königsberg 54: 188-195.

KAUNHOWEN F., RANGE 1906. Botanische Mitteilungen aus Masuren. Schr. phys.-ökon. Ges. Königsberg 46: 52-57.

KAWECKA A. 1991. Rośliny chronione, rzadkie i zagrożone w Suwalskim Parku Krajobrazowym i na terenach przyległych. Parki Nar. Rez. Przyr. 10(3-4): 93-109. (in Polish with English summary)

KAŹMIERCZAKOWA R., ZARZYCKI Z. (eds). 2001. Polska czerwona księga roślin. Instytut Botaniki im. W. Szafera PAN, Instytut Ochrony Przyrody PAN, Kraków, pp. 664. (in Polish with English summary)

KIRPLUK I. 1992. Godne ochrony stanowisko wełnianeczki alpejskiej Trichophorum alpinum na Pojezierzu Sejneńskim. Chrońmy Przyr. Ojcz. 48(1): 94-96. (in Polish)

KŁOSOWSKI S., TOMASZEWICZ H. 1979. Rzadkie i interesujące rośliny z Pojezierza Suwalskiego. Fragm. Flor. Geobot. 25: 371-375. (in Polish with German summary)

KONDRACKI J. 2001. Geografia regionalna Polski. 2nd edition. Wydawnictwo Naukowe PWN, Warszawa, pp. 441. (in Polish)

KOPPE F., KOPPE K. 1931. Zur Moosflora Ostpreussens. Unser Ostland 1(6): 299-394.

ŁACHACZ A., OLESIŃSKI L. 2000a. Flora i roślinność trzęsawiskowego torfowiska Jeziorko na Pojezierzu Mazurskim. Fragm. Flor. Geobot. Polonica 7: 129-144. (in Polish with English summary)

ŁACHACZ A., OLESIŃSKI L. 2000b. Interesujące torfowisko na Tatarskiej Górze (Pojezierze Mazurskie). Przegl. Przyr. 11(4): 37-42. (in Polish with English summary)

MAZUR W., SUDNIK-WÓJCIKOWSKA B., WERBLAN-JAKUBIEC H. 1978. Flora okolic Gib (Pojezierze Sejneńskie). Fragm. Flor. Geobot. 24(2): 225-257. (in Polish with German summary)

MIREK Z, MUSIAŁ L., WÓJCICKI J.J. 1997. Polish Herbaria. Polish Bot. Stud., Guideb. Ser. 18: 1-116.

PAŁCZYŃSKI A. 1975. Bagna Jaćwieskie (pradolina Biebrzy). Zagadnienia geobotaniczne, paleofitosocjologiczne i gospodarcze. Roczn. Nauk Roln. Ser. D 145: 1-232. (in Polish)

PAŁCZYŃSKI A. 1988. Bagna Biebrzańskie. Liga Ochrony Przyrody, Warszawa, pp. 104. (in Polish)

PAWLIKOWSKI P. 2008a. Nowe stanowiska zagrożonych gatunków torfowiskowych roślin naczyniowych i mchów w Suwalskim Parku Krajobrazowym i jego otulinie. Fragm. Flor. Geobot. Polonica 15(1): 43-50. (in Polish with English summary) 
PAWLIKOWSKI P. 2008b. Distribution and population size of the threatened fen orchid Liparis loeselii (L.) Rich. in the Lithuanian Lake District (NE Poland). Botanika-Steciana 12: 53-59.

PAWLIKOWSKI P. 2008c. Rzadkie i zagrożone rośliny naczyniowe torfowisk w dolinie Kunisianki na Pojezierzu Sejneńskim. Fragm. Flor. Geobot. Polonica 15(2): 205-212. (in Polish with English summary)

PIĘKOŚ-MIRKOWA H., WALUSIAK E. 2008. Baeothryon alpinum (L.) T.V. Egorova. Wełnianeczka alpejska. In: Z. Mirek, H. Piękoś-Mirkowa (eds), Czerwona Księga Karpat Polskich. Rośliny naczyniowe. Instytut Botaniki im. W. Szafera PAN, Kraków, pp. 500-502. (in Polish with English summary)

PLACKOWSKI R. 1980. Wełnianeczka alpejska Trichophorum alpinum w rezerwacie Jezioro Kolno w województwie suwalskim. Chrońmy Przyr. Ojcz. 36(4): 57-59. (in Polish)

POLAKOWSKI B. 1959. Rezerwat wierzby lapońskiej w Spytkowie w powiecie giżyckim. Chrońmy Przyr. Ojcz. 15(5): 4245. (in Polish)

RAŠOMAVIČIUS V. (eds) 2007. Lietuvos raudonoji knyga. Leidykla Lututë, Kaunas, pp. 799. (in Lithuanian with English Summary)

SCHULTZ R. 1892. Bericht über die botanische Erforschung des Kreises Goldap. Schr. phys.-ökon. Ges. Königsberg 54: 195-199.

SKURATOVICH A.N. 2005. Pukhonos alpid'skid' (L.) Egor. (=Trichophorum alpinum (L.) Pers.). In: G.P. Pashkov, L.V. Kalenda, V.N. Logvin, A.M. Petrikov (eds), Krasnaya Kniga Respubliki Belarus. Rasteniya. Belaruskaya Entsyklapedyya imeni Petrusya Brovki, Minsk, pp. 279-280. (in Russian)

SOKOŁOWSKI A.W. 1973. Rośliny naczyniowe Suwalskiego Parku Krajobrazowego. Prace Białostockiego Towarzystwa Naukowego 19: 85-101. (in Polish)

SOKOŁOWSKI A.W. 1978. Projektowany rezerwat Wiłkokuk w Puszczy Augustowskiej. Chrońmy Przyr. Ojcz. 34(1): 6065. (in Polish)

SOKOŁOWSKI A.W. 1988. Fitosocjologiczna charakterystyka zbiorowisk roślinnych Wigierskiego Parku Narodowego. Prace IBL 673: 3-146. (in Polish with English summary)

SOKOŁOWSKI A.W. 1989. Flora roślin naczyniowych rezerwatu Rospuda w Puszczy Augustowskiej. Parki Nar. Rez. Przyr. 9(1): 33-43. (in Polish with English summary)

SOKOŁOWSKI A.W. 1990. Flora roślin naczyniowych Wigierskiego Parku Narodowego. Parki Nar. Rez. Przyr. 9(4): 5-84. (in Polish with English summary)

SOKOŁOWSKI A.W. 1996. Zbiorowiska roślinne projektowanego rezerwatu Rospuda w Puszczy Augustowskiej. Ochr. Przyr. 53: 87-130. (in Polish with English summary)
STEFFEN H. 1912. Floristische Untersuchungen im Kreise Lyck. Jahres-Ber. Preuss. Bot. Ver. 1911: 36-43.

STEFFEN H. 1914. Zur Flora des Kreises Lyck. Schr. phys.ökon. Ges. Königsberg 54: 195-199.

ŚRODOŃ A. 1972. Roślinność Polski w Czwartorzędzie. In: W. Szafer, K. Zarzycki (eds), Szata roślinna Polski. Państwowe Wydawnictwo Naukowe, Warszawa, pp. 527-570. (in Polish)

TOBOLSKI K. 2003. Torfowiska na przykładzie Ziemi Świeckiej. Towarzystwo Przyjaciół Dolnej Wisły, Świecie, pp. 255. (in Polish)

TYSZKOWSKI M. 1992. Godne ochrony torfowisko nad jeziorem Białym koło Augustowa. Chrońmy Przyr. Ojcz. 48(6): 6872. (in Polish)

TYSZKOWSKI M. 1993. Eleocharitetum quinqueflorae Lüdi 1921 - the initial plant association of calcareous fens in Poland. Fragm. Flor. Geobot. 38(2): 621-626.

TYSZKOWSKI M. 1995. Wątlik błotny Hammarbya paludosa w Puszczy Augustowskiej. Chrońmy Przyr. Ojcz. 51(4): 7983. (in Polish)

ULBRICH E. 1916. Die Vegetationsverhältnisse des Rinnenseengebietes bei Strausberg. Verh. Bot. Ver. Prov. Brandenb. 57: 129-143.

ZAJĄC A. 1978. Atlas of distribution of vascular plants in Poland (ATPOL). Taxon 27(5-6): 481-484.

ZAJĄC A., ZAJĄC M. 2001. Atlas rozmieszczenia roślin naczyniowych w Polsce. Distribution Atlas of Vascular Plants in Poland. Laboratory of Computer Chorology, Institute of Botany, Jagiellonian University, Kraków, pp. 714 (in Polish and English)

ZAPAŁOWICZ H. 1906. Krytyczny przegląd roślinności Galicyi. Conspectus florae Galiciae criticus. 1. Akademia Umiejętności, Kraków, pp. 296. (in Polish and Latin)

ŻUKOWSKI W. 1969. Studia systematyczne i geograficzne nad podrodziną Cyperoideae w Polsce. Prace Kom. Biol. PTPN 33 (3): 1-132. (in Polish with English summary)

ŻUKOWSKI W. 2001. Baeothryon alpinum (L.) T. V. Egorova wełnianeczka alpejska. In: R. Kaźmierczakowa, Z. Zarzycki (eds), Polska czerwona księga roślin. Instytut Botaniki im. W. Szafera PAN, Instytut Ochrony Przyrody PAN, Kraków, pp. 472-473. (in Polish with English summary)

ŻUKOWSKI W., JACKOWIAK B. 1995. Lista roślin naczyniowych ginących i zagrożonych na Pomorzu Zachodnim i w Wielkopolsce. List of endangered and threatened vascular plants in Western Pomerania and Wielkopolska. In: W. Żukowski, B. Jackowiak (eds), Ginące i zagrożone rośliny naczyniowe Pomorza Zachodniego i Wielkopolski. Wydawnictwo Naukowe Bogucki, Poznań, pp. 9-96. (in Polish and English) 